\title{
Sekvence a objekty, př́spěvek k poznání formálních východisek spektrální hudby
}

\section{Sequences and objects, a contribution to understanding formal apsects of spectral music}

Petr Haas / 215418@mail.muni.cz

Department of Musicology, Masaryk University, Brno, CZ

\begin{abstract}
This text focuses on the formal foundations of spectral music. It is concerned with the elementary concept for the creation of a composition which consists of the generation of sequences of processed objects determined primarily by pitch. This concept has become paradigmatic in the field known as computer assisted composition, and whose formalisation represents a prototype of an instrument for the computer-assisted composition Esquisse (1987) created at the Institut de recherche et coordination acoustique/musique (IRCAM) for the needs of composers sharing the ideological foundations of spectral music. A similarity is brought to light between this concept and the compositional thinking of lannis Xenakis as applied to the creation of Stochastic Music Program (1962). The Esquisse insrument is analysed with the aid of an as yet unpublished manual provided by IRCAM, where it was used as an internal document.
\end{abstract}

\section{Key words}

Xenakis, spectral music, computer assisted composition, stochastic music program 


\section{Uvedení do problematiky, Esquisse, spektrální hudba, IRCAM a počítačem asistovaná kompozice}

Spektrální hudba je typ hudby ve vývojové linii Nové hudby. Obvykle vzniká v asistenci technologií, které skladatelům umožňují využívání technik elektronické hudby a výsledků analýzy zvukových spekter v oblasti instrumentální hudby. V ní se spektralismus projevuje primárně. Asistujícími technologiemi byly z počátku v 70. letech analogové sonagrafy (též sonografy) a od poloviny 80. let softwarové nástroje, jejichž vývojem se v té době začal zabývat pařížský IRCAM.

Součástí vývoje těchto softwarových nástrojů byla formalizace technik spektrální hudby, která postihla i způsob tvorby makro i mikro-tektonického plánu, stejně jako samotné myšlení o tom, jak kompozice vzniká, kde a jak proces tvorby začíná a jak je procesován. Reprezentantem a zároveň precedentem takové formalizace, je software z roku 1987 nazvaný Esquisse a označený jako kompozični prostředi pro počitačem asistovanou kompozici. Esquisse zůstalo prototypem a bylo krátce využíváno pouze v úzkém okruhu výzkumných pracovníků a skladatelů IRCAMu. Mimo jiné představuje koncept vznikání skladby, jenž vychází ze zpracovávání jednotlivých objektů určených primárně výškou tónu a v oblasti počítačem asistované kompozice se jako paradigma využívá dodnes. Koncept vykazuje shodu s kompozičním myšlením, které nejpozději od začátku 60. let uplatňoval Iannis Xenakis a jehož dokladem je Xenakisem vytvořený počítačový program Stochastic Music Program (1962). V jeho asistenci vznikaly skladby, které měly v názvu označení $S T$ tj. stochastic.

Esquisse je možné chápat jako další evidenci o povaze a původu formálnúho myšlení spektralismu. Jedinou publikovanou dokumentací o něm ale byla jeho prezentace na Computer Music Conference v roce 1988'. Od konce roku 2019 je však k dispozici také nikdy nepublikovaný manuál, jenž byl interním dokumentem IRCAMu a který pro potřeby výzkumu v oblasti počítačem asistované kompozice poskytl ze svého soukromého archivu skladatel Jean-Baptiste Barrière. Barrière byl v IRCAMu v letech 1984 až 1987 ředitel výzkumného týmu Recherche musicale, kde Esquisse v průběhu srpna až řijna roku 1987 vznikl. Barrière, jenž je zároveň spoluautorem Esquisse, potvrzuje, že „this was the one and only manual done at the time, and since software was not yet distributed it was mostly internal, even if some composers outside of Ircam may have used it."

\subsection{Ke vzniku, ideovým východiskům a metodám spektrální hudby}

Vznik toho, co se dnes označuje jako spektrální hudba, lze situovat do první poloviny 70 let. $\mathrm{V}$ tu dobu byly napsané první významné skladby nového stylu, zejména první kompozice z cyklu Les Espaces Acoustiques (G. Grisey, 1974 - 1985). Francouzská vývojová linie spek-

1 BAISNÉE, Pierre-Francois - BARRIÈRE, Jean-Baptsite - DALBAVIE, Marc - André et al. ESQUISSE: A Compositional Environment. In International Computer Music Conference Proceedings, 1988. Ann Arbor: Michigan Publishing, 1988, s. 108-118.

2 BARRIÈRE, Jean Baptiste. Emailová komunikace P. Haas - J. B. Barrière, 26. 9. 2019. 
tralismu je spojená s institucí IRCAM, který poskytoval potřebné technologické zázemí. Její představitelé reprezentovali nejen nové kompoziční myšlení, ale také hnutí ovlivněné environmentalismem a specifickou spiritualitou vycházející z psychedelie 60. let a souvisejících proudů new age určených snahou uchopit obsahy pojmů př́roda - přirozenost pomocí technologiií3. Tím je také daná povaha zájmu tzv. spektrálně komponujících skladatelů o fenomén zvuku: zvuk jako fyzikální jev je chápán jako něco přirozeného - přírodního a to mu dává legitimitu stát se vzorem či tzv. referenčním objektem strukturních vztahů kompozice. Využívány jsou přitom objektivní akustická data pocházející z analýzy zvukových spekter a techniky elektronické hudby přenášené v asistenci technologií do oblasti instrumentální hudby. Pro možnost takového komponování se většinou kompoziční proces odehrává ve frekvenční doméně a výsledky jsou pak s vybranou aproximací převáděny na hudební parametry. Frekvenční doména umožňuje po vzoru syntetizátorů komponovat témbr, jenž je specifickým typem složeného kmitu a v důsledku specifickým typem harmonie. Hranice mezi harmonií a témbrem pak mizí, témbr je předmětem kompozičního zájmu a metaforou kompozice $e^{4}$ V tom spočívá primární přínos spektrální hudby: obsahy pojmů harmonie a témbr se překrývají.

Strukturní vztahy v kompozici jsou pak vztahy mezi komponenty spektra a zvukové spektrum je reference takových strukturních vztahů. Běžnou aktivitou skladatelů je v návaznosti na tradici konkrétní hudby hledání a záznam spekter hudebního nebo jakéhokoliv jiného původu, jejich analýza, re-kompozice a následná interpretace orchestrem, který je v roli (re)syntetizátoru spektra (technika tzv. instrumentální či orchestrální syntézy).

Techniky spektrální hudby vystihuje trojice souvisejících pojmů: differentielle (...). liminale (....). transitoire (...). " ${ }^{5}$ První vyjadřuje zaměření na prirozenou rozdílnost mezi zvukovými spektry, která je předmětem zájmu a komponování, druhý poukazuje na snahu pracovat se skrytými, podprahovými jevy díky výsledkům výzkumu v oblasti fyziologické akustiky a psychoakustiky, a třetí se vztahuje k tendenci vytvářet kompozice jako přechod z jednoho stavu do druhého, z jednoho spektra ke spektru druhému. Jako nástroje k dosažení takových cílů jsou v naprosté většině případů využívány technologie. Od poloviny 80. let jsou těmito technologiemi nástroje pro počítačem asistovanou kompozici a proto je spektralismus možné vnímat jako její nejvýraznější, ideově vyhraněný proud. ${ }^{6}$

Mezi základní techniky ${ }^{7}$ patří: frekvenční a kruhová modulace ${ }^{8}$, manipulace s harmonicitou pomocí virtuálního fundamentálu9 , filtrování komponentů spekter, roztahování

3 Blíže např. DROTT, Eric. Spectralism, Politics and the Post-Industrial Imagination. In The Modernist Legacy: Essays on New Music. Björn Heile (ed). Farnham: Ashgate Publishing, 2009, s. 39-60.

4 Srovnej soubor textů od skladatelů a teoretiků blízkých spektrální hudbě a instituci IRCAM, viz Le Timbre: métaphore pour la composition. Jean-Baptiste Barrière (ed.). Paříz: IRCAM, Bourgois, 1991.

5 GRISEY, Gérard. La musique: Le devenir des sons. Darmstädter Beiträge zur Neuen Musik - Algorithrmus, Klang, Natur: Abkehr vorn Materialdenken?, 1984, č. XIX, Mainz: Schott's Sohne, 1984, s. 16-23, s. 16.

6 Základní představení spektrální hudby vč. bibliografie viz tématické číslo Contemporary Music Review, 2000, roč. 19 , č. 2.

7 Základní přehled technik spektrální hudby viz FINEBERG, Joshua. Guide to the basic concepts and techniques of spectral music. Contemporary Music Review, 2000, roč. 19, č. 2, s. 85-199.

8 Techniky zvukové syntézy.

9 Referencí harmonicity je harmonická řada, proces spočívá v hledání frekvence, která by mohla být první 
a komprese spektra při zachování frekvenčního poměru mezi jeho komponenty, posun (frequency shifting) ${ }^{10}$ a interpolace ${ }^{11}$.

\subsection{K pojmu počítačem asistovaná kompozice}

Pojem počítačem asistovaná kompozice $(\mathrm{CAC})^{12}$ označuje typ instrumentální komponované hudby vzniklé v asistenci počítače. Asistence počítače spočívá ve vykonávání formalizované kompoziční metody, která se tak stává algoritmem. Nástrojem formalizace je programovací jazyk, v současnosti jazyky tzv. vizuálni tj. laicky přístupné. Předmětem kompozice je symbolická reprezentace hudby, což je jeden z hlavních znaků, který takovou kompoziční praxi odlišuje od vytváření zvuku pomocí počítače. Artificiální CAC se uplatňuje takřka výhradně ve vývojové linii Nové hudby.

První pokusy s asistencí počítače pochází z poloviny 50. let a jejich primární smysl spočíval v demonstraci možnosti počítač jako tehdy novou technologii vůbec využit. V 60 . letech se objevily první umělecky autonomní a závažné asistované kompozice, z nichž pro vývoj Nové hudby mají význam primárně skladby Iannise Xenakise realizované pomocí Stochastic Music Program.

Období od poloviny 50. let do technologického boomu na přelomu 70. a 80. let lze chápat jako období tzv. pionýrské CAC určené mimo jiné nedostupností počítačů a specifickou směsí avantgardnosti a esoterisace jejich využívání. Po technologickém boomu je možné uvažovat novodobou či tzv. neotechnologickou ${ }^{13}$ fázi vývoje. Významným střediskem se stal IRCAM, kde byly na základně potřeby skladatelů blízkým ideovým východiskům spektrální hudby vyvinuté softwarové nástroje, které vytvořily paradigma pro nové typy nástrojů určených pro komponování v asistenci počítače. Později se tyto nástroje začaly využívat i mimo oblast určenou idejemi spektralismu a staly se nástroji CAC obecně.

S přispěním popularity spektrální hudby jako nového či alespoň tolerovaného akademického standardu se z CAC na konci 90. let stala specifická samostatná kategorie komponované hudby. V ní je spektralismus zmíněným nejvýraznějším ideově vyprofilovaným proudem. Jinak je oblast CAC typická relativně bezbřehou pluralitou stylové orientace skladatelů. Výstižným pojmem pro její popis je pojem rhizom filosofické dvojice G. Deleuze

harmonickou složkou (fundamentálem) harmonické řady, jejíž součástí je skupina tónů, kterou si skladatel přeje harmonizovat.

10 Přičítání nebo odečítání obvykle stále stejné hodnoty ke všem frekvencím spektra, poměr mezi komponenty spektra je zachován, při převodu frekvencí na výšky tónu se projeví rozdílnost mezi exponenciální posloupností frekvencí a lineární posloupností výšek tónů.

11 Technika k vytváření plynulých, primárně lineárních přechodů z jednoho stavu do druhého, v případě lineární interpol. jsou výsledkem hodnoty postupující po stále stejných krocích (aritmetická série), využíváno jak v oblasti výšek tónů, tak v oblasti délek tónu, jenž jsou za tímto účel vyjádřeny a chápány jako absolutní hodnoty.

$12 \mathrm{Z}$ anglického Computer Assisted Composition, také Computer Aided Composition.

13 HAAS, Petr. Počítačem asistovaná kompozice - precedenty formalizovaného myšlení. Disertační práce. Masarykova univerzita, Filozofická fakulta, Ústav hudební vědy, 2020. 
- F. Guattari. Každá jedna kompozice vzniklá jako CAC je jeden bod, jedna část rhizomu. Ten je specifickou strukturou, kterou není možné orientovat a říct, kde je nahoře, kde dole a potažmo kde vlevo nebo vpravo, „libovolný bod rhizomu může a musí být spojen s kterýmkoli jiným. Je to velký rozdil oproti stromu nebo kořeni, které určuji nějaký bod, ustavujici řád“14.

\section{Manuál Esquisse: mode d'emploi}

Poskytnutý manuál popisující kompoziční prostředí Esquisse je psán ve francouzském jazyce. Obsahuje celkem 52 strany formátu A4 včetně titulní stránky, stránky jsou volné, nesvázané, v pravém horním rohu je zjevná stopa po sešití kancelářskou svorkou. Byl vytvořen v textovém editoru Apple Mac plus nebo Apple Mac II. Za titulní stránkou je vložená volná strana, za nimi dvě nečíslované strany s obsahem manuálu a bezprostředně po té následuje celkem 48 číslovaných stran. Manuál neobsahuje žádné informace ke svému vydání, pouze na titulní stránce je uveden název dokumentu, autor a datace: ESQUISSE: MODE D’EMPLOI , P-F. Baisnée, Mai 1988, titulní stránka viz obr.1. K dispozici je také původní datový soubor, ze kterého byl manuál vytištěn.
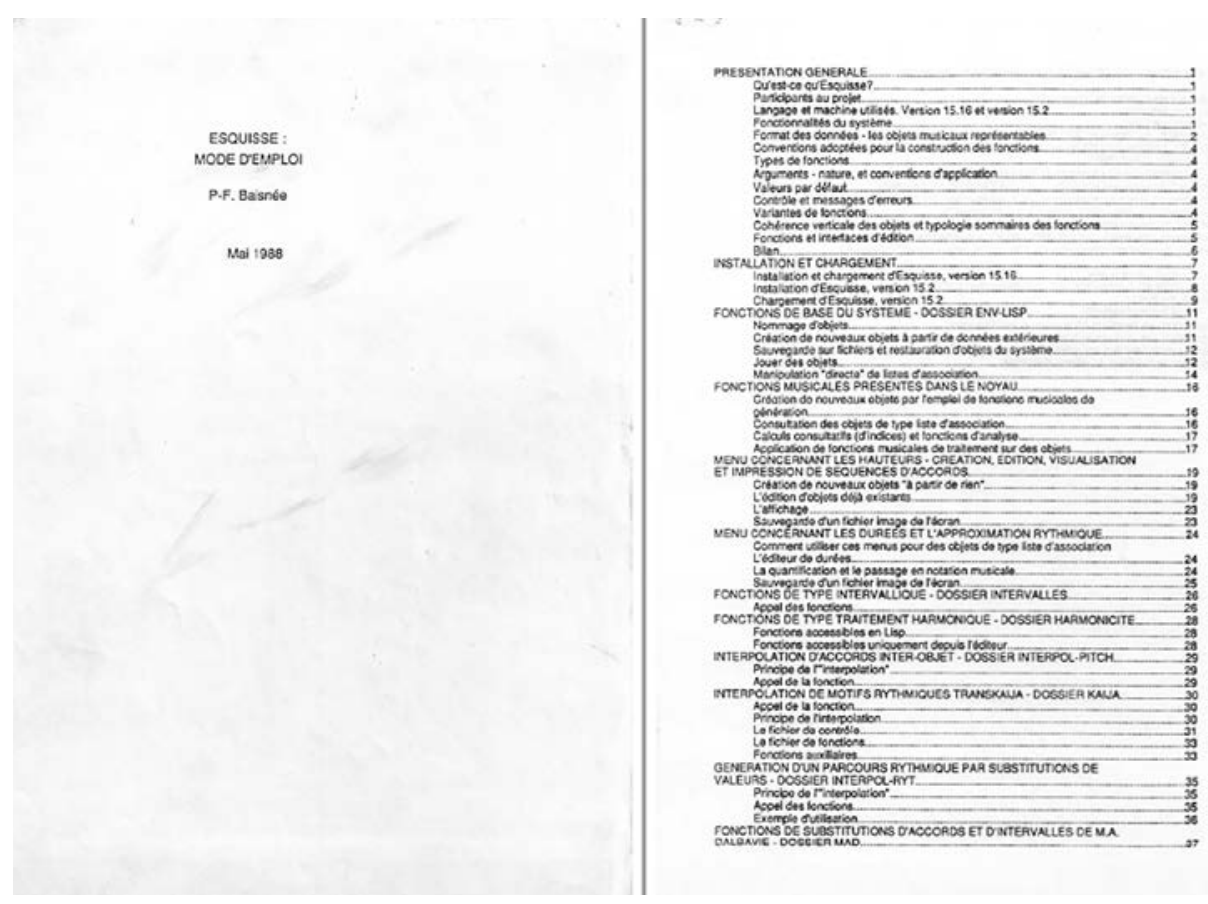

Obr. 1 Interní manuál IRCAMu ke kompozičnímu prostředí Esquisse; titulní stránka manuálu a v pořadí třetí strana tj. první strana obsahu, zdroj: soukromý archiv Jean-Baptiste Barrièra.

14 DELEUZE, Gilles - GUATTARI, Félix. Tisíc plošin. Praha: Herrmann \& synové, 2010, s. 13. 


\section{Esquisse, výzkum asistence, pre-kompozice, techniky spektralismu a objekt séquence d'accords}

„Esquisse est un environnement d'aide à la composition sur Mac Plus ou Mac II. C'est un ensemble de programmes qui ont été faijs, ou bien adaptés et regroupés, d'aồt à octobre 1987 pour l'essentiel, dans le double but de répondre aux besoins des compositeurs qui participaient au projet 'Aide à la composition' de la recherche musicale, et de provoquer une réflexion sur ce que pourrait être un système plus complet, et sur les moyens nécessaires pour y parvenir. Il s'agit donc d'un prototype. "15 Prezentace prototypu na veřejnosti proběhla v roce $1988^{16}$ a po té byl vývoj Esquisse (Esq) zastaven a jeho komponenty použity pro vývoj nového nástroje PatchWork. ${ }^{17}$ Autorský tým tvořili skladatelé Jean-Baptiste Barrière, Pierre-Francois Baisnée, Marc-André Dalbavie, Magnus Lindberg, Kaija Saariaho a dva počítačoví vědci Jacques Duthen a Yves Potard. Lze předpokládat, že Esq byl k dispozici i skladatelům, jenž v době jeho vznikání patřili do širšího okruhu IRCAMu. Součástí takového tehdejšího širšího okruhu byli pole slov Jean-Baptiste Barrièra Tristan Murail, Gérard Grisey, Philippe Hurel, Philippe Durville, Frédéric Durieux, Michael Jarrel, Camilo Rueda, Marco Stroppa, Serge Lemouton nebo Philippe Manoury. První tři jmenovaní patří mezi klíčové reprezentanty spektrální hudby, první dva pak mezi jeho obecně neznámější reprezentanty.

Esq je v principu nástroj pro uplatňování jednotlivých algoritmů, které představují formalizované kompoziční metody v nabídce nástroje. Výsledky skladatel viděl na monitoru počítače v reprezentaci, která vychází z konvenční notace, anebo si jej mohl nechat přehrát prostřednictvím připojeného externího syntetizátoru.

\subsection{Dva cíle a smysl vzniku Esquisee, spektra, témbr a výzkum možností asistence}

Esq byl v prvé řadě předmětem zmíněného výzkumného projektu aide à la composition, zůstal prototypem, zato ale prototypem představujícím úspěšnou predikci budoucí vývoje.

Autoři měli jasně stanované dva cíle uvedené při prezentaci Esq: „first of all, to meet the requirements of the composers who were working in the Musical Research Department at Ircam (namely J-B. Barriere, M-A. Dalbavie, M. Lindberg and K. Saariaho) ". Tento cíl se realizoval formalizací řady technik, které byly v podstatě rozšířením uvedených výchozích základ-

15 BAISNÉE, Pierre Francois. ESQUISSE: MODE D'EMPLOI. Francie: IRCAM, interní dokument, květen, 1988, s. 1.

16 BAISNÉE, Pierre-Francois - BARRIÈRE, Jean-Baptsite - DALBAVIE, Marc - André et al. ESQUISSE: A Compositional Environment. In International Computer Music Conference Proceedings, 1988. Ann Arbor: Michigan Publishing, 1988, s. 108-118.

17 Vývoj byl v podstatě adaptací první verze PatchWork, kterou vytvořil skladatel a počítačový vědec Mikael Laurson v letech 1985-1986, tehdy profesor na Sibelius-Akatemia v Helsinkách, k PatchWork viz LAURSON, Mikael - DUTHEN, Jacques. Patchwork a graphic language in Preform. In International Computer Music Conference Proceedings, 1989. Ann Arbor: Michigan Publishing, 1989, s. 172-175. 
ních technik spektrální hudby. Výsledkem rozšíření byla hlavně možnost výpočtu indexu jasnosti ${ }^{18}$ a možnost pracovat $\mathrm{s}$ daty o formantových oblastech hudebních nástrojü ${ }^{19}$. Autoři tyto techniky včetně technik rozšiřujících při prezentaci označili jako ,functions dealing with 'spectral' or timbral properties“20. Pro jejich použití Esq nabízel obousměrnou aproximativní konverzi fyzikálních parametrů zvuku na hudební parametry a reprezentaci převedených hudebních parametrů v konvenční notaci.

Druhý cíl reflektoval původní určení Esq jako předmětu výzkumného projektu. Představoval záměr zjistit, „what a more complete system could be, and what the necessary concepts and tools should be “. ${ }^{21}$ Vedeni snahou po vytvoření takového nástroje, který by byl v rámci Nové hudby relativně universální, vybavili autoři Esq také technikami pro manipulaci s intervaly ${ }^{22}$. Ty byly většinou ovlivněné metodami, jenž se později staly obsahem slavné publikace Penser la musique aujourd'hui ${ }^{23}$ Pierre Bouleze vydané ve stejném v roce, ve kterém byl Esq vytvořen.

\subsubsection{Výsledky výzkumu možností asistence, pre-kompoziční stádium a sekvence objektů}

Jedním ze dvou podstatných výsledků výzkumu asistence jako takové bylo vyjádření předpokladu, že budoucí novodobá asistence bude sloužit pro „pre-compositional' stage “24 ve kterém dojde $\mathrm{k}$ „elaboration of a rough material“. ${ }^{25}$ Uvažovaným výstupem tedy neměla být hotová skladba, ale výtvor určený k dalšímu zpracování. Tomu také odpovídá označení nástroje: esquisse čili skica nebo náčrtek. V oblasti spektrální hudby se pak skutečně takový 'pre-compositional' stage stal běžnou součástí celého kompozičního procesu. O něm bývá často konstatováno, že je sice kompletně asistován technologiemi, ale že na jeho konci je vždy tzv. intuice typu bezprostřední básnické inspirace. Takovou intuicí se míní motivace k zásahu do finální podoby díla, který je proveden bez asistence počítače a stojî tak v opozici s jakýmkoliv tzv. algoritmickým myšlením, které se spoléhá na výsledek uplatnění metody, vychází z předpokladu, že (rigorózním) dodržováním metody je možné dosáhnout hudebního estetična a proto také bezezbytku výsledek uplatnění metody

18 Index daný poměrem vyšších harmonických složek s cílem dosáhnout stejnojmenného efektu tj. obrazně řečeno jasné - zářivé barvy spektra - souzvuku.

19 Aplikování charakteru formantových vlastností na souzvuk (spektrum), k souzvuku se přidávají frekvence, které tvoří barvu imitovaného nástrojového témbru.

20 BAISNÉE, Pierre-Francois - BARRIÈRE, Jean-Baptsite - DALBAVIE, Marc - André et al. ESQUISSE: A Compositional Environment. In International Computer Music Conference Proceedings, 1988. Ann Arbor: Michigan Publishing, 1988, s. 111.

21 BAISNÉE - BARRIÈRE - DALBAVIE, op. cit., s. 108.

22 Filtrování, transpozice, zvětšování a zmenšování ambitu intervalu, přidávání intervalu do již existujících souzvuků (densifie les accords) aj.

23 BOULEZ, Pierre. Penser la musique aujourd'hui. Paříž: Gallimard, 1987.

24 BAISNÉE- BARRIÈRE- DALBAVIE, op. cit., s. 108.

25 Op. cit., s. 108. 
přijímá. V tomto smyslu bývá zdůrazňováno, že spektrální hudba není „truly algorithmic music ${ }^{\text {“26 }}$, byt algoritmy, tj. formalizované metody ke svému vznikání používá.

Druhým výstupem výzkumu byla formalizace procesování samotného kompozičního procesu. Výsledkem byl koncept postupného zpracovávání jednotlivých objektů pomocí metod tvořících nabídku Esq. Jeho uplatněním vznikala specifická hudební forma sekvenční povahy, která se mohla projevit jak v oblasti mikro-tektoniky, tak i při plánování juxtapozice větších celků. Autoři koncept označili ve francouzském jazyce jako séquence d'accords, tedy „séquence d'accords“ 27 psáno díky použití slova accord v uvedených uvozovkách. Pojem accord totiž evokuje tonální harmonii a svět před-moderní hudby, čímž se minimálně podle autorů Esq dostával do rozporu s tím, k čemu byl Esq vytvořen. V anglicky psaném textu prezentace Esq z roku 1988 je použit pojem chord a „chord sequence“ 28 rovněž v uvozovkách.

\subsection{Objekt séquence d'accords}

Základní jednotkou, na kterou byly uplatňované funkce jako kompoziční metody, byl objekt (objet). Přesněji řečeno, funkce byly uplatňovány na obsah objektu, nebot objekt samotný je možné si představit jako nositele obsahu, který může být pokaždé jiný. Objekt a obsah objektu jsou tedy dvě různé věci. Obsahem objektu byly hudební parametry nebo hodnoty fyzikálních veličin popisujících zvukovou událost. V hodnotách a parametrech existovala v návaznosti na posloupnost jejich zpracování hierarchie. Primární hodnotou nebo parametrem byla výška tónu udaná symbolicky jako specifické číslo přriřazené k výškám tónu tónového systému, anebo jako frekvence v hertzech. Počet takových parametrů či hodnot, tj. počet prvků tvořících obsah objektu, mohl být relativně libovolný, maximálně minimální počet prvků musel být ale roven jedné, nebot objekt obsahující nula prvků byl jen teoretický. Práce v asistenci Esq pak vypadala jako postupné uplatňování funkcí na jednotlivé objekty, čímž vznikala sekvence objektů. Ta tvořila výstup z práce s Esq.

Objekt je v Esq tím, u čeho počítačem asistovaný kompoziční proces začíná a tím, co tvoří základní jednotku, jejímž opakováním vzniká budoucí skladba. To, co je určeno k opakování, je objekt jako nositel relativně libovolného obsahu. Objekt-akord se uplatněním funkce stává objekt-sekvence akordi̊ a ten je tím, co je v jádru Esq základním objektem, k němuž se vztahují všechny operace, slovy z interního manuálu řečeno: „dans le noyau d'Esquisse, un seul type d'objet est représenté, qu'on pourrait appeler , séquence d'accords“"29. Objekt-sekvence akordů může být tvořen i jen jedním jediným objektem-akord.

26 FINEBERG, Joshua. Guide to the basic concepts and techniques of spectral music. Contemporary Music Review, 2000, roč. 19, č. 2, s. 110 .

27 BAISNÉE, Pierre Francois. ESQUISSE: MODE D'EMPLOI. Francie: IRCAM, interní dokument, květen, 1988, s. 2.

28 BAISNÉE - BARRIÈRE - DALBAVIE, op. cit., s. 109.

29 BAISNÉE, op. cit., s. 2. 
Objekt séquence d'accords představuje specifickou universální formu, kterou získávají všechny výstupy z Esq. Pokud skladatel sekvenci chápe jako závaznou, ta se pak stává formou budoucí skladby. Výsledky práce se sekvencí byly reprezentované v editoru séquences d'accords viz obr. 2. Editor zobrazoval pouze výšku a umístění noty tj. prvku v objektu jako $\mathrm{v}$ časovém intervalu.

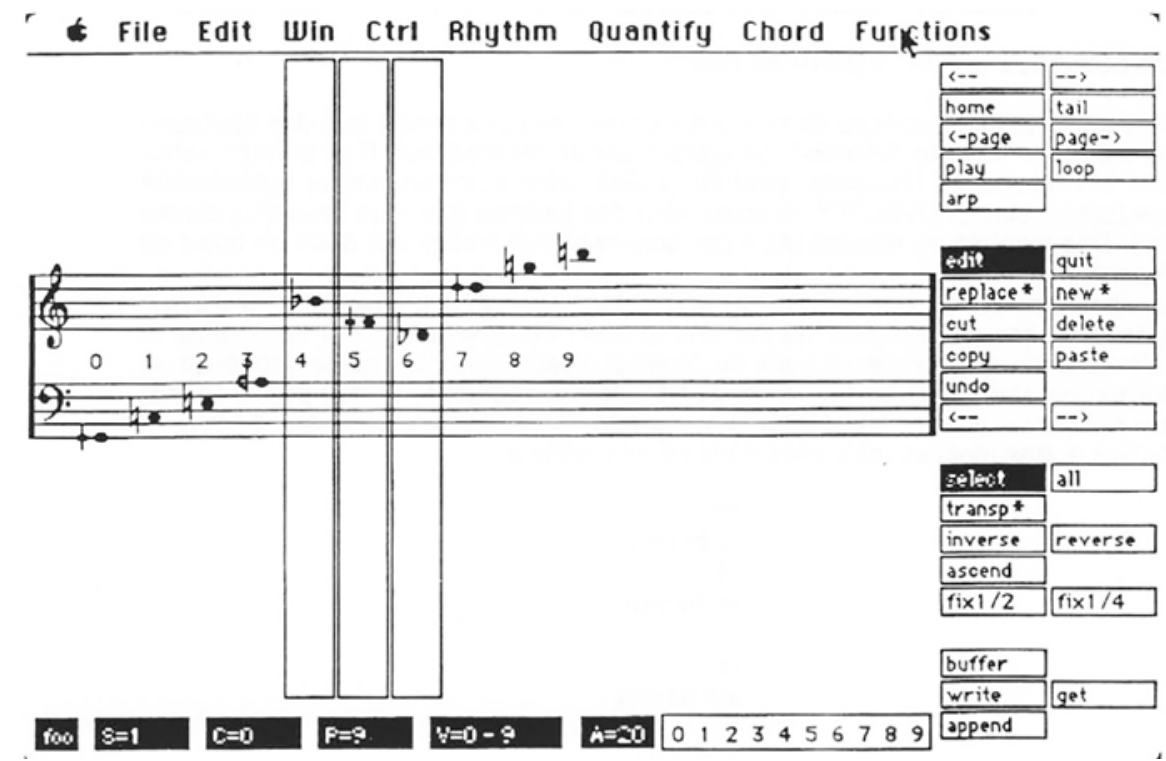

Obr. 2 Editor séquences d'accords v Esquisse; editor je reprezentací výsledků uplatnění funkcí na jednotlivé objekty-akordy a jejich sekvenci, pořadí výšek tónu odpovídá jejich postupnému nastupování v čase objektu a potažmo skladby, zdroj: BAISNÉE, Pierre Francois. ESQUISSE: MODE D'EMPLOI. Francie: IRCAM, interní dokument, květen, 1988, s. 19.

\subsubsection{Objekt jako časový interval, koncept horizontální organizace}

Objekt, který je na začátku objekt-akord, je chápán jako nositel obsahu, jenž je určen ke strukturování. Pro možnost dát obsahu objektu časový rozměr, sloužil v Esq jednoduchý koncept shodný s praxí elektronické hudby realizované v digitálním prostředí.

Objekt-akord je z pohledu horizontální organizace časový interval, jenž má počátek a zatím blíže neurčený konec. Počátek takového objektu-akord je okamžik nula. K času nula se přičítají chronometrické údaje určující zahájení znění každého dalšího prvku, jenž tvoří obsah objektu. Jinak řečeno, prvky se umistují do objektu jako na časovou osu do bodu zmíněného zahájení jejich znění. Časová organizace objektu-sekvence akordů je pak realizována v principu stejně. Každý objekt-akord je chápan jako prvek sekvence určený okamžikem svého zjevu v rámci sekvence. Okamžik zjevu byl označován jako „attack-ti- 
$m e$ “. ${ }^{30} \mathrm{~V}$ běžné terminologii, kterou autoři Esq rovněž používají, je vztah prvního prvku k bodu nula označován jako onset-time a vztahy ostatních prvků v prvnímu prvku jako offset-time. Attack-time, stejně jako onset i offset-time byly a jsou udávány v chronometrických jednotkách. K těmto hodnotám byl přidáván chronometrický údaj o délce tónu, čímž se obsah objektu stal plně časově určeným. Pokud byla délka tónu delší, než časový interval mezi tónem a tónem následujícím, tóny se překrývaly a vytvářely vícehlas.

\subsubsection{Komponování s objektem séquence d'accords, př́klad skladby vzniklé v asistenci Esquisse}

Postupné zpracovávání objektů a vznikání sekvence je přirozeně formotvorné a pro skladatele formativní, podobně jako komponování v místnosti, kde tikají hodiny v tempu 60 úderů za minutu. Postupné zpracovávání jednoho objektu-akord za druhým může logicky motivovat k úvahám o vytváření makro nebo mikro-tektonického plánu, jenž bude založen na řadě oddílů jako řadě postupně se proměňujících objektů. Koncept svádí k sekvencím typu A, A', A' ', A ' ' nebo ( $\mathrm{a}^{\prime} \mathrm{a}^{\prime \prime}$ ) (b b $\mathrm{b}^{\prime} \mathrm{b}^{\prime \prime}$ ') atd. Povaha takových sekvencí koresponduje s povahou metod spektrální hudby, konkrétně pak s podmínkou či zaměřením se na tranzitornî1 jevy. Koncept séquence d'accords lze chápat jako koncept latentně tranzitorní formy. Tranzitorní pak mohou být celé makro-tektonické oddíly skladby, stejně jako mikro-tektonika v přechodech od jedné výšky ke druhé. Taková latence ale není jediná. Koncept lze současně chápat jako motivaci k práci s blokovou sazbou, kdy nevznikají sekvence typu A, A', A' ', A ' ' ' ale sekvence zcela kontrastní objektů. Východiskem k takovému chápání sekvencí mohou být skladby Edgara Varése, kterého tzv. spektrálně pracující skladatelé chápou jako svého předchůdce. Příkladné jsou v tomto smyslu jeho obecně známé kompozice jako Arcana (1927, pro orchestr), Ionisation (1931, pro 13 perkusních nástrojů) či Hyperprism (1923, pro 9 dechových nástrojů a 7 perkusních nástrojů). Řadu klíčových skladeb spektralismu lze vykládat jako výsledek specifické blokové sazby, ve které jsou ostré přechody obvykle nivelizovány a bloky představují jednotlivá různá spektra či různá zpracování stáje jednoho a toho samého spektra.

Autoři v prezentaci uváděli několik příkladů skladeb vzniklých v asistenci Esq. Jedna z nich je Le Déluge, ${ }^{32}$ kterou komponoval Marc-André Dalbavie. Citován je výstup z pre-kompozičního procesu bez udání obsazení viz obr. 3. Východiskem pro citovanou část se stalo třináct skupin výšek tónů, které je možné v souvislosti s používanou terminologií označit jako souzvuky či akordy. V příkladu jsou výchozí souzvuky onačeny písmenem $a$ s uvedeným pořadovým číslem 1 až 13 . Každý z těchto třinácti souzvuků je prvním souzvukem v oddílu, kterých je také třináct a připomínají takty. Chybí ale proporce a oddíly je vhodné chápat jako krátké séquence d'accords, z nichž třináctá obsahuje jen jeden souzvuk. První souzvuk v sekvenci je výchozí a po něm následují dvě jeho varianty, které se

30 BAISNÉE, op. cit., s. 3.

31 Pojem tranzitorní je zde používán jako ekvivalent francouzského transitoire, viz kapitola 1.1.

32 Skladba měla být dokončena a pak premiérovaná v roce 1989, v dostupných seznamech děl Marc-Andrého Dalbaviela však chybí. 
liší narůstající mírou harmonicity komponovanou uplatněním algoritmu pro práci s virtuálním fundamentálem. Vztahy mezi souzvuky dané vyvozováním jednoho souzvuku ze souzvuku předcházejícího, jsou v příkladu naznačeny čárkami v indexu u písmene $a$.
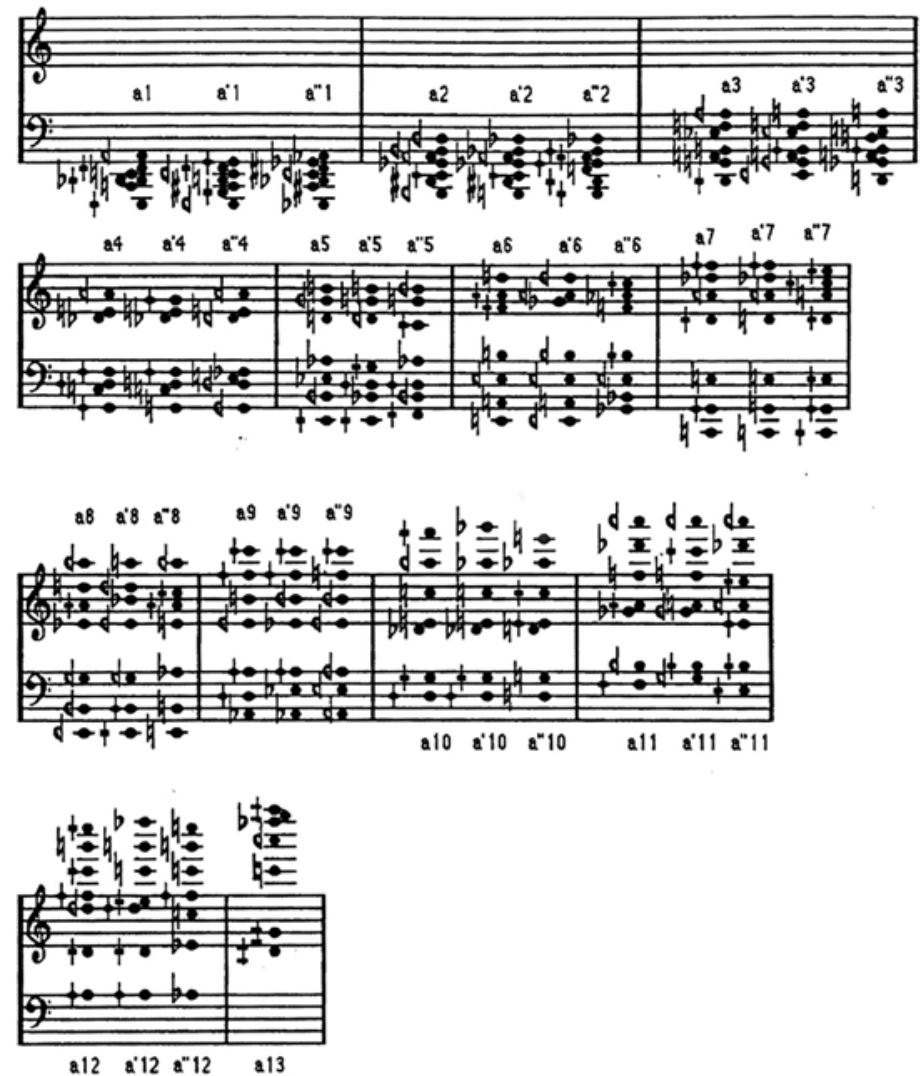

Obr. 3 Ukázka výstupu z Esq, část pre-kompozičního procesu skladby Le Déluge; třináct oddílů, třináct séquence d'accords, každá začíná souzvukem označeným písmenem a s uvedeným pořadovým číslem 1 až 13, za souzvukem pak následují jeho varianty $a^{\prime}, a^{\prime \prime}$, akcidentála ve tvaru kř́žku s horizontálním ramenem znamená zvýšení o 1/4 tónu, zdroj: BAISNÉE, Pierre-Francois - BARRIĖRE, Jean-Baptsite - DALBAVIE, Marc - André et al. ESQUISSE: A Compositional Environment. In International Computer Music Conference Proceedings, 1988. Ann Arbor: Michigan Publishing, 1988, s. 108-118, s. 114.

\subsubsection{Koncept séquence d'accords v současnosti, objekty chord a chord-seq}

Esq byl výzkumným projektem a koncept séquence d’accords jedním z výstupů výzkumu, který byl použit při koncipování dalších následujících nástrojů pro CAC, tj. chronologic- 
ky a v logice vývoje: PatchWork (1989), OpenMusic (1996) a PWGL (2002) ${ }^{33}$. Všechny tyto nástroje sdílejí jedno paradigma, jehož součástí je koncept séquence d'accords. V průběhu následujících 90. let k objektu-akord a k objektu-sekvence přibyla v nabídce těchto nástrojů ještě řada jiných objektů, které se staly nositeli různých nových skupin různých parametrů a stejně tak různých jednohlasých a vícehlasých struktur. Výchozí koncept séquence d'accords je ale patrný v existenci dvou základních objektů, které se nejpozději od druhé třetiny 90. let označují jako chord a chord-sequence, tedy stejně, jako séquence d'accords v anglicky psané prezentaci Esq z roku 1988. Chord je objekt, jehož obsahem jsou výšky tónů a objekt chrod-sequence je sekvencí takových objektů chord, časová organizace je identická. Současná podoba objektů v nástroji OpenMusic, viz obr 4.

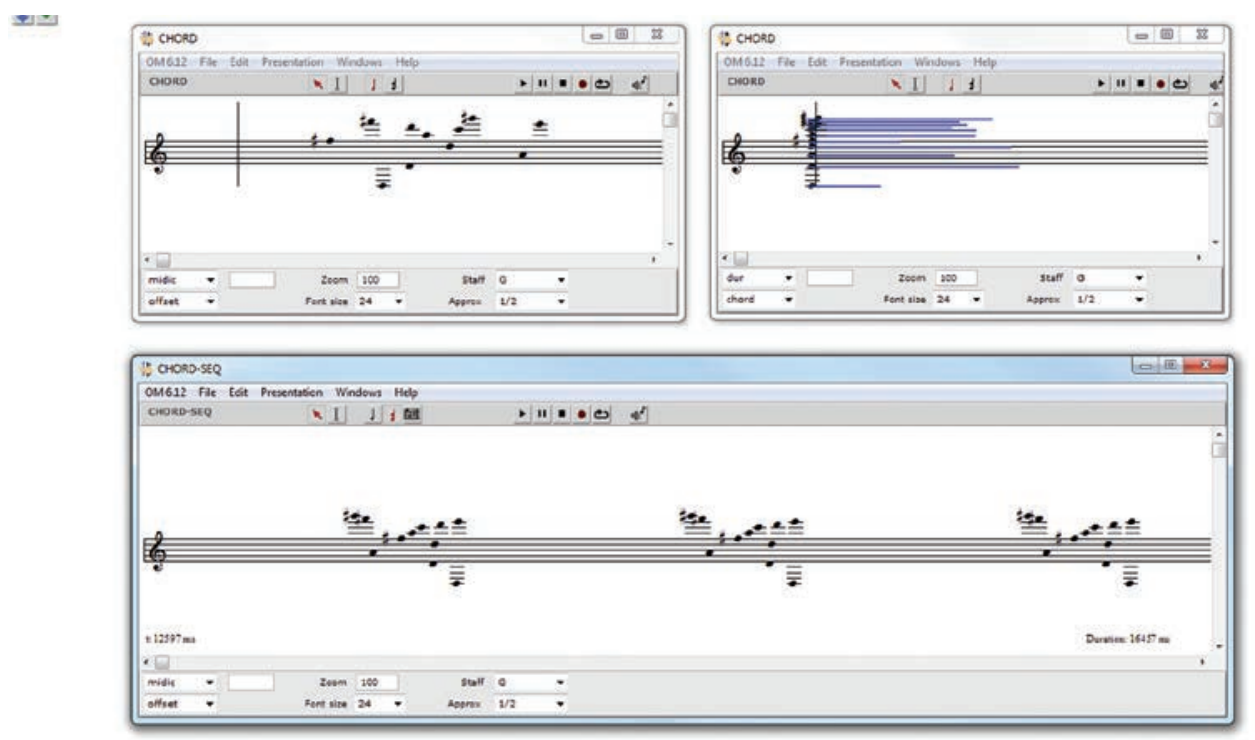

Obr. 4 Objekty chord a chord-sequence; koncept séquence d'accords je prítomný i v soudobých nástrojích pro CAC, názvy objektů jsou již anglicky, zde objekt chord s náhodně vybranými výškami tónů a pod ním objekt chord-seq tj. chord-sequence, ve kterém je pro názornost obsah objektu chord třikrát zopakován, svislá čára v notové osnově u objektu chord vlevo nahoře označuje bod nula, ke kterému se vztahuje hodnota onset-time, rozestupy jsou tvořené pomocí hodnoty offset-time, na pravé straně je objekt chord s výškami v superpozici a s proporčně vyjádřenými délkami jednotlivých výšek tónů pomocí modrých čar, vytvořeno v programovacích prostředí pro CAC OpenMusic, zdroj: autor.

Možnosti časové orientace obsahu jsou v principu stále stejné, vztahují se k pomyslnému počátku objektu chord anebo objektu chord-sequence a využívají hodnoty onset-time a offset-time. Uživatel nových nástrojů nastupujících po Esq může koncept sekvencí se

33 Elementární přehled vývoje, viz ASSAYAG, Gérard - RUEDA, Camilo - LAURSON, Mikael (et al.). Computer-Assisted Composition at IRCAM - From PatchWork to OpenMusic. Computer Music Journal, 1999, roč. 23, č. 3. s. 59-72. 
všemi jeho vlastnostmi a aspekty využít, ale stejně tak jej může ignorovat a díky řadě jiných objektů využívat jiné metody a postupy. Pokud je možné chápat práci v Esq díky konceptu séquence d'accords jako predestinaci tranzitorní formy či bokové sazby, pak to samé již o práci v nástrojích nastupujících po Esq prohlásit možné není. Uživatel má již řadu jiných možností, jak kompoziční proces realizovat a procesovat. Navíc tyto nové nástroje již nepředstavují jen nabídku funkcí, ale jsou plně programovatelné a skladatel vytváŕí algoritmy a potenciálně i objekty sám.

\section{Východiska konceptu objekt séquence d'accords, akordy jako spektra, Xenakis a zvukové masy}

Způsob, jakým byla v konceptu séquence d'accords řešena organizace času pomocí absolutních hodnot chronometrických jednotek, poukazuje na již zmíněnou praxi elektronické hudby realizované v digitálním prostředí, kde je koncept onset a offset-time základním nástrojem uchopení času. ${ }^{34}$ Způsob uvažování hudební formy, jejíž podstatou je sekvence objektů, ale vykazuje významnou shodu s formálním myšlením, kterým se od poloviny 50. let zabýval Iannis Xenakis a které pak v asistenci počítače opakovaně realizoval od roku 1962. V principu se jedná o zzukové masy, jenž vznikají v procesu srovnatelným s procesem vznikání séquence d'accords.

Současně ale také může být séquence d'accords jen prostým vyjádřením potřeby vytvořit tranzitorní formu pro postupnou proměnu objektů tj. akordů chápaných v roli spekter.

\subsection{Akordy jako spektra}

Autoři Esq označili jednotlivé objekty tvořící sekvenci objektů jako akordy. Nezvolili jiný termín, např. skupina nebo množina, byt prostředí, ve kterém Esq vznikl, je výrazně ovlivněné specifickým scientismem a pojmy z oblasti modulární matematiky, teorie pravděpodobnosti nebo teorie množin, jsou v něm zcela běžné. Nezvolili ani žádný označující pojem, jenž by se vztahoval k času jako k něčemu, co je existenčně spjaté se zvukem. Zvolili pojem akord, který se vztahuje k problematice spolu-zaznívání výšek tónů nebo obecně akustických signálů a který je běžně uchopován bez vztahu k délce tónů. Objekt akord by se nemusel jmenovat akord, mohl se jmenovat např. časový interval nebo kostra času ${ }^{35}$.

34 Pro základní orientaci viz The computer music tutorial. Curtis Roads (ed.). Cambridge, London: The MIT Press, 1996.

35 Pojem kostra času (skeleton of time) je jedním z pojmů, kterým v roce 1980 na přednášce na Darmstädter Ferienkurse popisoval klíčový představitel spektralismus Gérard Grisey hudební čas, text přednašky byl publikován v roce 1987, viz GRISEY, Gerard. Tempus ex Machina: A composer's reflections on musical time. Contemporary Music Review, 1987, roč. 2, s. 239-275. Nahrávka přednášky pronesené 22. 07. 1980, viz 30. Internationale Ferienkurse für Neue Musik, Darmstadt 1980. Internationales Musikinstitut Darmstadt, archiv. Titul: Lecture Gérard Grisey / Tristan Murail. ShelfmarkI: MD-M-26298. DRA-Code: B015873965. 
Jmenuje se ale akord a vztahuje se tak k něčemu, co je primárně vertikální povahy, co je specifickou abstrakcí takové vertikály či superpozice ve smyslu jejího uvažování bez vztahu k času, a co je a priori zaměřeno na kvalitu spolu-zaznívání a co se takovou kvalitou přímo zabývá, co ji reprezentuje. Pojem akord je sice tradičním pojmem, ale současně svým obsahem odpovídá zaměření tzv. spektrálně píšících skladatelů na oblast harmonie, která díky komponování ve frekvenční doméně představuje stejnou doménu, jako je témbr. Objekt séquence d’accords by mohl být v principu chápán jako sekvence spekter či témbru a motivace jeho vzniku jako latentně tranzitorní formy pak jen jako vyhovění požadavkům kladeným na spektrální kompozici. Výchozí otázka položená před návrhem Esq ve znění: jak procesovat vznik kompozičního procesu tak, aby vznikla forma vhodných vlastností, mohla být zodpovězena návrhem sekvence zpracovávající a priori zvukové respektive sou-zvukové objekty, pro jejichž pojmenování se využil pojem akord. S tím koresponduje i poznámka v prezentaci z roku 1988 o různých typech pojetí objektů, které mohou být kromě jiného „spectra (seen as a chord with pitch and amplitude information)." ${ }^{6}$

Koncept onset - offset time pak dává takové formě nástroje k organizaci času.

\subsection{Séquence d'accords jako sekvence mračen zvuku, SMP a lannis Xenakis}

Pojmy mračna zvuků a zvukové masy pochází z dnes již obecně známého konceptu tzv. stochastické hudby Iannise Xenakise. Výchozí návrh byl publikován v roce 1958 v Gravesaner Blätter ${ }^{37}$ a mezi lety 1960-1962 pak ve stejném revue Xenakis postupně zveřejnil jeho konečnou podobu ${ }^{38}$. První Xenakisem publikovaná zmínka o možnostech využít pro komponování teorii pravděpodobnosti a s její pomocí formovat soundmasses (v německy psaných textech klangensembles), ale pochází již z roku $1956^{39}$. Sám Xenakis však situoval počátek konceptu už do roku 1954: „In 1954 I denounced linear thought (polyphony), and demonstrated the contradictions of serial music [XENAKIS, Yánnis. La crise de la musique sérielle. Gravesaner Blätter, 1955, č. 1, s. 2-4.]. In its place I proposed a world of soundmasses, vast groups of sound-events, clouds, and galaxies governed by new characteristics such as density, degree of order, and rate of change, which required definitions and realizations using probability theory [XENAKIS, Janis. Wahrscheinlichkeitstheorie und Music. Gravesaner Blätter, 1956, č. 6, s. 28-34.]. Thus stochastic music was born" "40. Pro sledování původu myšlení, které ved-

\footnotetext{
36 BAISNÉE - BARRIÈRE - DALBAVIE, op. cit., s. 110.

37 XENAKIS, Yannis. In Search of Stochastic Music. Gravesaner Blätter, 1958, č. 11/12, s. 112-122.

38 XENAKIS, Iannis. Elements of Stochastic Music. Gravesaner Blätter, 1960, č. 18, s. 84-105; XENAKIS, Iannis. Elements of Stochastic Music. Gravesaner Blätter, 1960, č. 19/20, s. 140-150, v německé verzi textu ve stejném vydání revue je u názvu textu uvedena číslovka označující druhý díl: Gruntlagen einer stochatischen Music II, s. 128-139.; XENAKIS, Iannis. Elements of Stochastic Music III. Gravesaner Blätter, 1961, č. 21, s. 113-124.; XENAKIS, Iannis. Elements of Stochastic Music IV. Gravesaner Blätter, 1961, č. 22, s. 144-155.; XENAKIS, Iannis. Elements of Stochastic Music. Gravesaner Blätter, 1962, č. 23/24, s. 169-184.
}

39 XENAKIS, Janis. Wahrscheinlichkeitstheorie und Music. Gravesaner Blätter, 1956, č. 6, s. 28-34.

40 XENAKIS, Iannis. Formalized Music - thought and mathematics in composition. Revised edition. Stuyvesant NY: Pendragon Press, 1992, s. 182, s. 19. 
lo Xenakise k vytvoření SMP a které mohlo ovlivnit budoucí spektralismus, je podstatné, že tzv. stochastická hudba vychází z úvah, jenž vznikly v době, kdy neexistovaly anebo nebyly publikovány žádné precedenty s hudebním vyžitím digitálních počítačů a kdy přístup k takovým počítačům byl pro Xenakise nebo jiné umělce prakticky vyloučen. ${ }^{41}$

Jedním z podstatných výstupů konceptu stochastické hudby byly metody použité při komponování skladby Achorripsis pro velký ansámbl (1957). Nejpozději v lednu 1962 pak skladatel dokončil jednoduchý počítačový program, jenž byl formalizaci takových metod a do určité míry imitoval proces vznikání Achorripsis. Xenakis jej vytvořil jako sled několika málo kroků vedoucích ke vzniku skladby využívající vždy stále stejný formální model. Skladby vznikaly opakovaným spouštěním programu, který se jmenoval Stochastic Music Program (SMP) a umožňoval komponování pouze jednoho typu hudby s použitím pouze jedné metody. Skladatel proces ovládat primárně pomocí vstupních dat. Různost výstupů pak zajištovalo používání náhodných procesů. V květnu 1962 měla premiéru skladba ST/10-1 pro komorní soubor, která byla první kompozicí vzniklou v asistenci SMP. Později stejným zpo̊sobem vznikly skladby ST/48-1, 240162, 1962; ST/10-1, 080262, 1962; ST/4-1, 080262, smyčcový kvartet, 1962; Eonta, pro šest nástrojů, 1964; ST/10-3, Atrées pro devět nástrojů a bicí, 1962; Morsima-Amorisima, pro čtyři nástroje, 1962; ST/4-2, smyčcový kvartet, $1962 .{ }^{42}$

Popis SMP byl publikován v roce $1963 \mathrm{v}$ monografii Musiques formelles ${ }^{43}$ a o dva roky později současně německy a anglicky v Gravesaner Blätter ${ }^{44}$. V roce 1978 matematik a hudebník John Myhill představil upravenou verzi $S M P^{45}$. Součástí popisu úprav je i popis původní Xenakisem vytvořená verze a hlavně níže uvedené schématické vyjádření jejího původního fungování ze 60 . let. ${ }^{46}$

41 K prvnímu využití digitálního počítače k hudební tvorbě došlo v roce 1955 (D. Caplin, D. Prinz, Velká Británie), zpráva o pokusu publikována 1959, první pokus s vyluzováním zvuku pomocí počítače pochází z roku 1951 (počítač CSIRAC, Austrálie), nejednalo se však o digitální syntézu ale o „houkání“ (hook base synthesis) melodie pomocí integrovaného hlásiče chybového hlášení, pokus publikován pravděpodobně až 1997, první digitální syntéza provedena v roce 1957 (M. Mathews, USA), publikováno v roce 1959, viz HAAS, Petr. Počítačem asistovaná kompozice - precedenty formalizovaného myšlení. Disertační práce. Masarykova univerzita, Filozofická fakulta, Ústav hudební vědy, 2020, kapitoly A_1.1.5., A_2.1.1., A_2.1.1.1.

42 Označení ST je zkratka slova stochastic, číslice za lomítkem představují počet instruments použitých při generování partitury, následující číslice za pomlčkou označuje pořadové číslo skladby vytvořené pro stejně početný instrumentár. Xenakis za názvy obvykle přidával také informaci o dni vygenerování partitury ve tvaru den, měsíc, rok, např. 240162 tj. 24. ledna 1962.

43 XENAKIS, Iannis. Musiques formelles-nouveaux principes formels de composition musicale. Paříz: La revue musicale, 1963.

44 XENAKIS, Iannis. Free Stochastic Music from the Computer. Gravesaner Blätter, 1965, č. 26, s. 79-92.

45 MYHILL, John. Some Simplifications and Improvements in the Stochastic Music Program. In International Computer Music Conference Proceedings. Ann Arbor: Michigan Publishing, 1978, s. 272-317, dostupné také online. Online [2019-06-06] URL: https://quod.lib.umich.edu/i/icmc/bbp2372.1978.023/28/-some-simplifications-and-improvements-in-the-stochastic?page=root;size=125; view=pdf .

46 Méně detailní schéma je také v textu bakalářské práce z roku 1972, která je současně jediným manuálem k SMP. Autorem práce je účastník Xenakisových kurzů v Center for Mathematical and Automated Music a student School of Music, Indiana University Bloomington Bruce Rogers, viz ROGERS, Bruce. A user's manual for Stochastic Music Program. Bakalářská práce, Indiana University Bloomington-School of Music, 1972. 


\subsubsection{Program jako nová forma}

Xenakis vnímal algoritmus vzniklý ve snaze formalizovat metodu jako program představující „new musical form." a jejich tvorbě se Xenakis věnoval ještě před tím, než se rozhodl využívat pro komponování asistenci počítače. $\mathrm{V}$ tu dobu jim říkal flow chart, viz obr. 5 ukazující flow chart skladby Achorripsis. Pro pozdější možnost využít k vykonání programu počítač bylo nutné program přepsat do programovacího jazyka. „Once the programme has been transcribed into a form the computer is capable of assimilating [...] a series of test runs can he made to disclose errors of logic and orthography and to determine the starting values of the parameters introduced as variables." 48

Zmíněné flow chart z konce 50. let jsou první evidencí o tendencích formalizovat kompoziční metodu, což je vzhledem k matematizovaným kompozičním metodám logický postoj, a SMP lze vnímat jako zcela přirozeně následující krok vedoucí k plné algoritmizaci kompoziční práce.

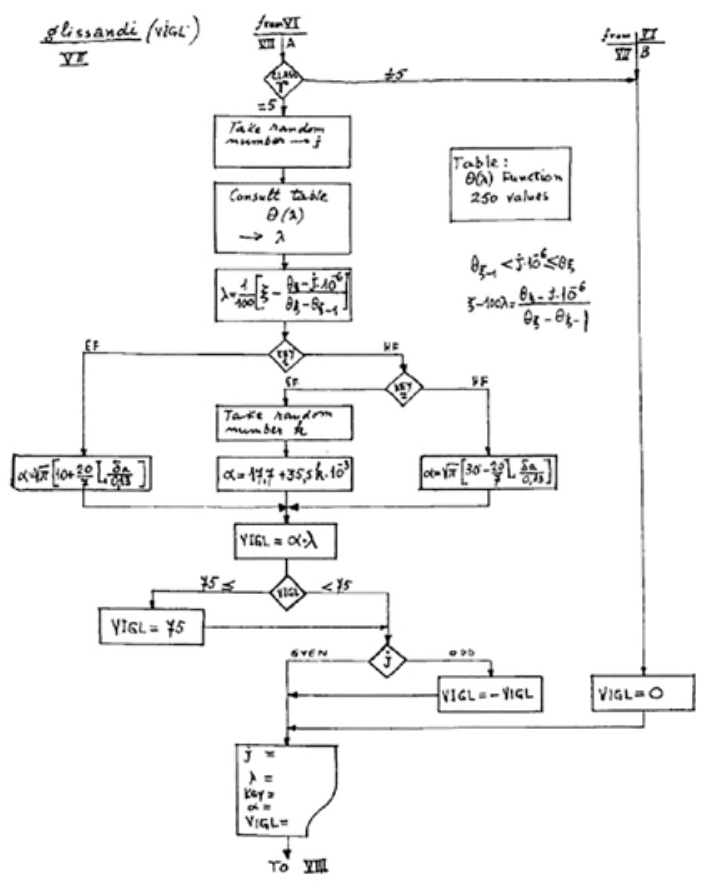

Fig. V-1. Excerpt from the First Flow Chart of Achomipsis

Obr. 5 Část flow chart skladby Achorripsis (1957); flow chart je uveden s původním popiskem, zdroj: XENAKIS, lannis. Formalized Music - thought and mathematics in composition.

47 XENAKIS, Iannis. Formalized Music - thought and mathematics in composition. Revised edition. Stuyvesant NY: Pendragon Press, 1992, s. 144.

48 XENAKIS, Iannis. Free Stochastic Music from the Computer. Gravesaner Blätter, 1965, č. 26, s. 79-92, s. 87 . 
Revised edition. Stuyvesant NY: Pendragon Press, 1992, s. 135.

\subsubsection{SMP, délka, hustota a témbr zvukového mračna}

$S M P$ v podstatě vytváří skladby jako sekvence složené z jednotlivých mračen zvuku. Každé mračno je v principu akustický objem, který Xenakis strukturuje pomocí práce s jeho délkou, hustotou a témbrem. Ten ovládá pomocí práce s předem připravenými tř́dami nástrojouých barev (timbre-classes). Strukturování se děje pomocí náhodných - stochastických procesů a vytváří různé varianty mračen podle stále stejného strukturního modelu. Mezi mračny vznikají různé přechody, jenž mohou být překvapivě náhle kontrastní způsobem, jako když náhle padne vysoké číslo při hře s kostkami, a stejně tak mohou mračna na sebe zcela plynule navazovat nebo vytvářet dojem, že jedno mračno pozvolna přechází v druhé. Pro skladatele sdílející výše popsané ideové východiska spektralismu, kde témbr je metaforou kompozice a kde důraz je kladen na jeho postupnou proměnu z jednoho stavu do druhého, mohly být takové př́stupy logicky inspirativní. Čelní představitel francouzské linie spektrální hudby Gérard Grisey se s nimi mohl seznámit, když v roce 1972 navštěvoval přednášky Xenakise na Darmstädter Ferienkurse.

\subsubsection{SMP, sekvence a mračna, popis programu}

Základní jednotkou, kterou SMP zpracovává, je sekvence (sequence). Tak jednotku nazývá Xenakis, v níže uvedeném schématu je pro označení téhož použit pojem section. Každý jeden cyklus, který je spuštěním programu vykonán, vytvoří jednu sekvenci. Sekvence je úsek skladby v délce v řádu jednotek sekund a obsahuje určitý počet not (notes). Počet not v sekvenci je uvažován, a počítačem zpracováván, jako počet not za určitý časový interval, kterým je jedna sekunda. Počet not za sekundu udává hustotu not (density of notes) každé sekvence. Každé takové notě je v průběhu generování sekvence přiřazována výška, délka, dynamický průběh, barva tj. nástroj z instrumentáře skladby, eventuálně rychlost glissanda a také okamžik nástupu zahájení znění v rámci sekvence.

Skladby vytvořené v asistenci $S M P$ jsou sledem sekvencí, které v podstatě představují zmiňovaná mračna zvuků. Každý cyklus generuje jedno mračno, jejichž různost ovlivňuje náhodný proces. Ten tvoří varianty skladatelem zadaných vstupních dat.

Níže uvedené schéma představuje jednotlivé kroky prováděné $S M P$ a zároveň stav při prvním spuštění programu, kdy je definována první sekce $(\mathrm{S}=1)$ a první nota $\mathrm{N}(\mathrm{N}=1)$. Tzv. průměrné hodnoty jsou vypočítávány s použitím náhodného procesu a obvykle na základě Xenakisem zadávaných limitních hodnot. Používané náhodné procesy jsou řízené a velmi komplexní. 




Obr. 6 Schéma fungování SMP; zdroj: MYHILL, John. Some Simplifications and Improvements in the Stochastic Music Program. In International Computer Music Conference Proceedings. Ann Arbor: Michigan Publishing, 1978, s. 272.

\section{Popisky ke schématu SMP}

- compute length of section; vypočítání délky sekce na základě skladatelem udané „mean duration" 49 ,

- compute density of section $S$; výpočet hustoty sekce na základě „mean density of (...) cloud $^{\text {"50 }}$,

- define orchestra for section $S$; výpočet procentuální účasti jednotlivých nástrojových skupin (timbre-classes) na výsledném témbru, timbre-classes zadával skladatel, výpočet účasti byl náhodný proces,

49 XENAKIS, Iannis. Free Stochastic Music from the Computer. Gravesaner Blätter, 1965, č. 26, s. 79-92, s. 82.

50 XENAKIS, op.cit., s. 82. 
- n=1; zahájení práce na první notě sekce,

- compute attack time of note $n$; tj. „determining the point of time when the note $n$ of the sequence (...) occurs. "51, výpočet vycházel z limitních hodnot zadaných skladatelem a vztahoval se k počátku sekce,

- determine instrument of note $n$; přiřazení nástroje náhodným výběrem z jednotlivých timbre-classes,

- compute pitch of note $n$; přiřazení výšky tónu již instrumentované notě $n$, výšky tónu jsou vybírány náhodným výběrem na základě předcházející výšky tónu a rozsahu nástroje,

- compute gliss speed of note $n$; vypočítání rychlosti glissanda v př́ípadě, kdy instrumentář glissando umožňoval, skladatel udával maximální hodnotu rychlosti v počtech půltónů za sekundu,

- computer duration of note $n$; výpočet délky tónu v sekundách na základě skladatelem udané maximální délky,

- determine intensity-form of note $n$; výběr z daných 44 dynamických průběhů (dynamic form),

následuje další cyklus tj. sekce anebo ukončení programu.

\subsubsection{Simulace výstupu z SMP pomocí objektů chord a chord-seq}

Podobnost mezi konceptem séquence d'accords a fungováním SMP umožňuje výstup z SMP simulovat pomocí současné podoby konceptu séquence d'accords tj. pomocí konceptu, jenž využívá objekty chord a chord-sequence viz obr. 7. Při simulaci byly využity jednoduché generátory náhodných čísel, které v zadaných limitech hodnot imitovaly zcela nesrovnatelně komplikovanější stochastické procesy použité Xenakisem. Předmětem simulace ale není přesné napodobení SMP, nýbrž postihnutí základních formálních aspektů jeho fungování ve vztahu ke konceptu séquence d'accords. Každé jedno mračno představuje jeden chord a je v simulaci zpracováno pětkrát, jako by $S M P$ vykonal pět cyklů (sekvencí). Tak vznikla sekvence, kterou v simulaci reprezentuje objekt chord-sequence.

51 XENAKIS, Iannis. Free Stochastic Music from the Computer. Gravesaner Blätter, 1965, č. 26, s. 79-92, s. 84 . 


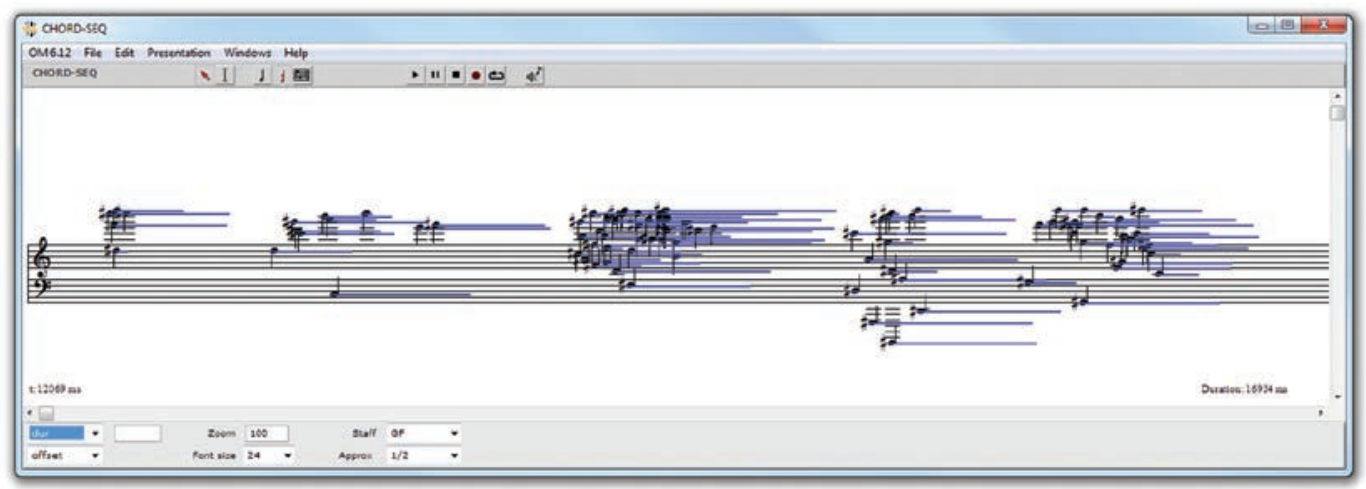

Obr. 7 Simulace výstupu z SMP pomocí objektu chord-sequence; v objektu chord-seq tj. chord-sequence, je pět různých objektů chord, které vytvář́ konečnou sekvenci, modře je proporčně vyjádřená délka tónu udaná v milisekundách, stejně jako zbytek časové organizace využívající onset time a offset-time, tj. v principu attack- time, každý objekt v sekci má délku cca 3 až 5 sekund, celková délka sekce je necelých 17 sekund, vytvořeno v programovacích prostředí pro CAC OpenMusic, zdroj: autor.

\section{Závěr}

Tvz. kompoziční prostředí nazvané Esquisse a vytvořené v roce 1987 obsahuje formalizovaný koncept procesu vznikání hudební kompozice, který je současně predestinací hudební formy. Taková forma se může projevovat v mikro-tektonickém i makro-tektonickém plánu. Původ konceptu lze vyvozovat z požadavku na tranzitorní povahu hudební kompozice vznikající v intencích výchozích idejí spektrální hudby a koncept lze pak chápat jako formalizaci modelu relativně universální formy použitelné pro spektralismem ovlivněné komponování. Taková relativně universální forma by mohla být popsaná jako sekvence složená z objektů, které se od sebe různě liší, vždy však je taková různost zaměřená na detail. Díky různosti v detailech má sekvence charakter posloupnosti vzniklé rozfázováním procesu přeměny jednoho objektu v objekt následující. Předmětem komponování je pak hybnost takového procesu přeměny, stejně jako struktura jednotlivých objektů a tím i relativní ostrost přechodů mezi fázemi přeměny. Čím vyšší ostrost, tím kontrastnější jsou jednotlivé přechody a uplatnění formy pak vytváří efekt blokové sazby. Obsah objektů je ve své výchozí podobě v superpozici a je určen k rozvíjení v čase. Rozvíjení obsahu objektů v čase se děje postupným vkládáním jejich jednotlivých komponentů na pomyslnou časovou osu. Stejným způsobem jsou pak vkládány na stejně pomyslnou časovou osu samotné objekty, čímž vniká sekvence objektů. Sekvence je výslednou skladbou.

Taková forma vykazuje řadu shodných rysů s výsledky uplatnění kompoziční metody, která vychází z konceptu stochastické hudby Iannise Xenakise a jejíž formalizaci představuje Xenakisův Stochastic Music Program z roku 1962. Shoda spočívá ve vytváření sekvencí složených 
z objektů, jenž jsou v případě Xenakise zvukovými mračny či mračny zvukư. Stejně jako objekty v kompozičním prostředí Esquisse, i mračna jsou něčím, co nemá pevně dané rozměry, tj. délku ano obsah, co je v tomto smyslu bez pevného tvaru a co svůj tvar teprve získá strukturováním svého obsahu. Shodný je také zpo̊sob, jak je takové strukturování prováděno. Dochází k němu pomocí časové orientace prvků, jenž tvoří obsah po sobě jdoucích objektů či mračen. Hudební čas je v obou případech uvažován v absolutních chronometrických hodnotách, prvky jsou vkládány na pomyslnou časovou osu a klíčový parametr je okamžik zahájení znění v rámci objektu či mračna. Taková organizace je shodná s praxí elektronické hudby. Samotná úvaha o možnosti tvořit mračna a pracovat s jejich hustotou, délkou a témbrem, strukturovat je jako specifický typ akustické hmoty či akustického objemu, je ale s vysokou pravděpodobní vzniklá bez ovlivnění digitálními technologiemi a vychází z autonomních úvah Xenakise o hudební formě, které pochází z doby před etablováním digitálních technologii jako takových. První evidencí o jejich realizování jsou schématické flow-charts, tj. specifické kompoziční algoritmy vytvořené s papírem a tužkou.

Uvažování o možnosti tvořit a formovat mračna a nechávat vzniknout sekvence určené postupnou proměnou mračen, lze chápat jako vliv Xenakise na formální východiska spektralismu. Na rozdíl od tzv. spektrálně pracujících skladatelů ale Xenakis nevytvářel svá mračna a zvukové masy na základě akustických vlastností zpracovávaného tónového materiálu a nejedná se o zvuková spektra, která by měla předobraz v nějaké akustické reálii typu instrumentální barva nebo zvuk přírodniny. V tomto smyslu je Xenakisova tvorba zcela ne-spektrální a díky tomu se může její vliv na spektrální hudbu jevit menší, než ve skutečnosti je.

\section{Bibliografie}

ASSAYAG, Gérard - CASTELLENGO, Michèle - MALHERBE, Claudy. Nouvelles techniques instrumentales composition et formalisation - rapports de recherche $N^{\circ}$ 38. Paříž: IRCAM, 1985.

ASSAYAG, Gérard - RUEDA, Camilo. The Music Representation Project at IRCAM. In International Computer Music Conference Proceedings, 1993. Ann Arbor: Michigan Publishing, 1993, 206-209.

ASSAYAG, Gérard. Visual Programming in Music. In International Computer Music Conference Proceedings, 1995. Ann Arbor: Michigan Publishing, 1995, s. 73-76.

ASSAYAG, Gérard - RUEDA, Camilo - LAURSON, Mikael (et al.). Computer-Assisted Composition at IRCAM - From PatchWork to OpenMusic. Computer Music Journal, 1999, roč. 23, č. 3. s. 59-72.

BAISNÉE, Pierre-Francois - BARRIÈRE, Jean-Baptsite - DALBAVIE, Marc - André et al. ESQUISSE: A Compositional Environment. In International Computer Music Conference Proceedings, 1988. Ann Arbor: Michigan Publishing, 1988, s. 108-118, s. 108.

BAISNÉE, Pierre Francois. ESQUISSE: MODE D'EMPLOI. Francie: IRCAM, interní dokument, květen, 1988.

BOULEZ, Pierre. Penser la musique aujourd'hui. Paříž: Gallimard, 1987.

Contemporary Music Review, 2000, roč. 19, č. 2.

DELEUZE, Gilles - GUATTARI, Félix. Tisic plošin. Praha: Herrmann \& synové, 2010.

DONIN, Nicolas. Sonic Imprints: Instrumental Resynthesis in Contemporary Music. In Musical Listening in the Age of Technological Reproduction. Borio Gianmario (ed.), Routledge 2015, s. 323-341. 
DROTT, Eric. Spectralism, Politics and the Post-Industrial Imagination. In The Modernist Legacy: Essays on New Music. Björn Heile (ed). Farnham: Ashgate Publishing, 2009, s. 39-60.

DUFOURT, Hugues. Musique spectrale. In DUFOURT, Hugues. Musique, pouvoir, écriture. Paris: Christian Bourgois, 1991, s. 289-294.

FINEBERG, Joshua. Musical examples. Contemporary Music Review, 2000, roč. 19, č. 2, s. 115-134.

FINEBERG, Joshua. Guide to the basic concepts and techniques of spectral music. Contemporary Music Review, 2000, roč. 19, č. 2, s. 85-199.

GRISEY, Gérard. La musique: Le devenir des sons. Darmstädter Beiträge zur Neuen Musik, 1984, č. XIX. Mainz: Schott's Sohne, 1984, s. 16-23.

GRISEY, Gérard. Tempus ex Machina: A composer's reflections on musical time. Contemporary Music Review, 1987, roč. 2, s. 239-275.

GRISEY, Gérard. Structuration des timbres dans la musique instrumentale. In Le Timbre: métaphore pour la composition. Jean-Baptiste Barrière (ed.). Paříž: IRCAM, Bourgois, 1991, s. 352-385.

GRISEY, Gérard. À propos de la synthèse instrumentale. In GRISEY, Gérard: Écrits - ou l'invention de la musique spectrale. Guy Lelong (ed.). Paříž: Édition MF, 2008, s. 35-37.

HASEGAWA, Robert. Gérard Grisey and The ,Nature' of Harmony. Music Analysis, 2009, roč, 28, č. 2/3, s. 349-371.

LAURSON, Mikael - DUTHEN, Jacques. Patchwork a graphic language in Preform. In International Computer Music Conference Proceedings, 1989. Ann Arbor: Michigan Publishing, 1989, s. 172-175.

LAURSON, Mikael - KUUSKANKARE, Mika. PWGL. A Novel Visual Language based on Common Lisp, CLOS and OpenGL. In International Computer Music Conference Proceedings, 2002. Ann Arbor: Michigan Publishing, 2002, s. 142-145.

Le Timbre: métaphore pour la composition. Jean-Baptiste Barrière (ed.). Paříž: IRCAM, Bourgois, 1991.

MYHILL, John. Some Simplifications and Improvements in the Stochastic Music Program. In International Computer Music Conference Proceedings. Ann Arbor: Michigan Publishing, 1978, s. 272-317.

ROGERS, Bruce. A user's manual for Stochastic Music Program. Bakalářská práce, Indiana University Bloomington-Scholl of Music, 1972.

SYROVÝ, Václav. Hudebni akustika. Praha: Akademie múzických umění v Praze, 2013.

The computer music tutorial. Curtis Roads (ed.). Cambridge, London: The MIT Press, 1996.

XENAKIS, Janis. Wahrscheinlichkeitstheorie und Music. Gravesaner Blätter, 1956, č.6, s. 28-34.

XENAKIS, Yannis. In Search of Stochastic Music. Gravesaner Blätter, 1958, č. 11/12, s. 112-122.

XENAKIS, Iannis. Elements of Stochastic Music. Gravesaner Blätter, 1960, č. 18, s. 84-105.

XENAKIS, Iannis. Elements of Stochastic Music. Gravesaner Blätter, 1960, č. 19/20, s. 140-150.

XENAKIS, Iannis. Elements of Stochastic Music III. Gravesaner Blätter, 1961, č. 21, s. 113-124.

XENAKIS, Iannis. Elements of Stochastic Music IV. Gravesaner Blätter, 1961, č. 22, s. 144-155.

XENAKIS, Iannis. Elements of Stochastic Music. Gravesaner Blätter, 1962, č. 23/24, s. 169-184.

XENAKIS, Iannis. Musiques formelles-nouveaux principes formels de composition musicale. Paříž: La revue musicale, 1963.

XENAKIS, Iannis. Free Stochastic Music from the Computer. Gravesaner Blätter, 1965, č. 26, s. 79-92.

XENAKIS, Iannis - Rahn, John. Sieves. Perspectives of New Music, 1990, s. 58-78.

XENAKIS, Iannis. Formalized Music - thought and mathematics in composition. Revised edition. Stuyvesant NY: Pendragon Press, 1992.

XENAKIS, Yánnis. La crise de la musique sérielle. Gravesaner Blätter, 1955, č. 1, s. 2-4. 